\title{
Modern State of Land Resources and Analysis of the Level of Ruralization within the Steppe Regions in the Asian Part of Russia
}

\author{
Chibilyov (jr.) A.A.* \\ Department of socio-economic geography \\ Institute of Steppe OFRC UB RAS \\ Orenburg, Russia \\ e-mail: a.a.ml@mail.ru
}

\author{
Meleshkin D.S. \\ Department of socio-economic geography \\ Institute of Steppe OFRC UB RAS \\ Orenburg, Russia \\ e-mail: aventureiro@mail.ru
}

\author{
Grigorevsky D.V. \\ Department of socio-economic geography \\ Institute of Steppe OFRC UB RAS \\ Orenburg, Russia \\ e-mail: grag92@mail.ru
}

\begin{abstract}
Landscapes of the steppe zone in Asian part of Russia have undergone a large-scale agricultural development, experienced a negative effect due to agrarian-economical activity for last 2 centuries. The Virgin Land Campaign, aftermaths of which formed a complex of problems having the national character, was the brightest example of fatal anthropogenic transformation of steppe landscapes. A reduction of agricultural use of the territory due to economical crisis in 1990-s promoted to decrease a bit the anthropogenic load. To reveal peculiarities and disproportions of a land resources use in the steppe territories of the Asian part of Russia, a retrospective analysis of a state and special features of the land fund structure was conducted within 8 subjects of RF: Orenburgskaya, Chelyabinskaya, Kurganskaya, Tyumenskaya, Omskaya, Novosibirskaya oblasts, the Republic of Bashkortostan and Altaisky Kray. Indicators of rural and agricultural population for 1995-2008 were analyzed on the base of a ratio on which a level of ruralization within the studied regions was calculated. As a result, a schematic map was built to visualize spatial distribution and interconnections between indicators of the square of arable lands, the level of ruralization and the structure of agricultural lands.
\end{abstract}

Keywords - land fund; level of ruralization; virgin lands developmet; steppe regions; Asian part of Russia.

\section{INTRODUCTION}

The steppe zone in the Asian part of Russia had been a natural polygon for global state projects and experiments during the long period of time. The bright example of the experiment was the Virgin Land Campaign, aftermaths of which formed a complex of problems having a national scale: depopulation, soil degradation, desertification, formation of the unclaimed lands' fund, reduction of water resources and biological diversity. Traditional technologies which had been practiced for many decades in agriculture led to degradation of vast territories of arable lands, to the growth of climate aridity, depletion of biological diversity due to an anthropogenic load on agrolandscapes. On the base of these factors nowadays it is increasing the topicality of ecologization of plant growing by means of a transfer to landscape-adaptive systems of agriculture and resource-saving technologies directed to form a high balance and stability of landscapes, to restore and stabilize soil fertility, to reduce resource expenditure, and to conserve biological diversity. In connection with it, it is reasonable to conduct a retrospective analysis of a state and special features of the land fund's structure in the steppe regions in the Asian part of Russia to estimate a level of ruralization in the studied regions.

The agrarian sphere is the significant component of the national security of the country and a strategical sector taking into account a border location of the steppe regions in Asian Russia. One of the principal tasks is to provide a transfer to ecologically stable agriculture on the studied territory. In developed countries introduction of modern forms to arrange agricultural production happens on the background of a reduction of unproductive agricultural lands, and rendering of recreational and ecological services. Complex development of rural territories should take into account problems of poordevelopment of territories and a relatively low population. From the point of view of geopolitical, ecological and socialeconomical positions, a problem of "white spots" formation on the agricultural map of the country and compression of the Russian developed space demands to be carefully elaborated.

\section{MATERIALS AND METHODS}

Problems to estimate the dynamics of land resource reclamation as well as their modern state were described by Nekrich A.S., Lyuri D.I. (2016, 2019) [1, 2]. The authors in their work analyzed change of an amount of the arable lands square. A scientific team under the leadership by Chibilyov A.A. (2016) calculated the soil-ecological index as an integral indicator to optimize a land use structure in the steppe zone of South Ural [3]. Levykin S.V. and his 
colleagues paid a special attention to problems of steppe land use (2019) [4]. A large quantity of papers was devoted to problems of virgin lands development. Kazmin M.A. (2004) considered territorial peculiarities of land use in the post-war period [5]. Tomilin V.N. (2009) studied in details a problem of virgin and fallow lands [6]. Semyonov E.A. (2018) considered issues of virgin and fallow lands reclamation [7]. Evolution of a rural area and a changing geography of the agrarian sector were described in details in the monograph by Alexeev A.I. and Mironenko N.S. (2004) [8], also, this problem was studied by Kuzina I.M. (1996, 2004) [9, 10], and Robinson G.M. (1995) [11]. The principal approaches as well as problems of the geographical study in a rural area were considered in works by Kovalyov S.A. (1963) [12], Alexeev A.I. (1990) [13] and others.

In the mesoregion of the steppe zone in the Asian part of Russia the urbanization period and division of the area into urbanized territories and rural areas fell on XX century. Spaces out cities and between them geographically belonging to rural territories continue to play the most significant role in the country development. In spite of a fact that the considerable part of mining operations happens in a rural area, agriculture remains the main sector of the economy here. To estimate a social-economical potential of these vast territories is significant to know a level of their "ruralization". "Ruraliztion" of the territory is defined by not only a specific weight or density of rural population living there (RP), but an indicator of its residents who are occupied in agriculture forming agricultural population (AP). A ratio of AP and RP reflects a level of ruralization (LR) in the territories.

The assessment of LR, a study of its spatial distribution in the context of RF subjects and municipal units are important from the point of view of an analysis of social and productive problems in the rural territory.
A ratio of agricultural population and rural population is laid on the base of calculation of the level of ruralization (1). Indicators of RF subjects for 1995-2008 taken from open sources by the Federal State Statistic Service were used as the informational base of the study $[14,15]$ (Table 1$)$.

$$
L R=A P / R P * 100 \%
$$

The used methodology [10] was modified for the studied mesoregion; it supposed a ranking of region-subjects according to three categories: agrarian - LR is more $30 \%$; semi-agrarian - LR is 15-30\%; diversified - LR is less $15 \%$.

\section{RESULTS}

$8 \mathrm{RF}$ subjects located in 3 federal districts are taken as regions formed the steppe zone of Asian Russia. They are: Orenburgskaya oblast, the Republic of Bashkortostan, Chelyabinskaya oblast, Kurganskaya oblast, Tyumenskaya oblast, Omskaya oblast, Novosibirskaya oblast and Altaisky Kray. The square of the examined mesoregion is 1.1 million $\mathrm{km}^{2}$ (6.3\% of the RF square); the population reaches to 18.9 million people (13.1\% of the RF population). Steppe and forests-steppe of South Ural and West Siberia form the most significant agricultural belt that had been touched by the Virgin Land Campaign during 1954-1963 [16]. In 2020 there are the 72-anniversary of the start of the large-scale realization of "the Stalin Plan to Transform a Nature of Steppe and Forests-Steppe" (Resolution of Council Ministers of the USSR and the CPSU (b) № 3960 on 20 October) and the 66anniversry of the start of the mass reclamation of virgin and fallow lands.

TABLE I. DYNAMICS OF THE LEVEL OF RURALIZATION AND RURAL AND AGRICULTURAL POPULATION IN THE STEPPE ZONES OF ASIAN RUSSIA

\begin{tabular}{|c|c|c|c|c|c|c|c|c|c|c|}
\hline \multicolumn{2}{|l|}{ Region } & \multirow{2}{*}{ 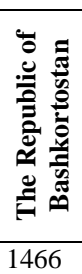 } & \multirow{2}{*}{ 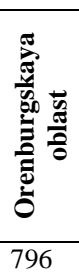 } & \multirow{2}{*}{ 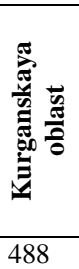 } & \multirow{2}{*}{ 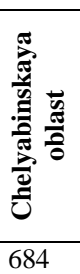 } & \multirow{2}{*}{ 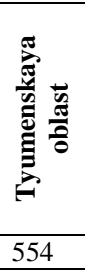 } & \multirow{2}{*}{ 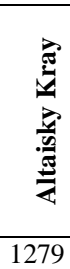 } & \multirow{2}{*}{ 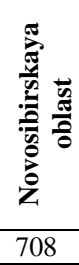 } & \multirow{2}{*}{ 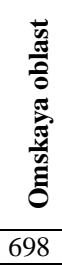 } & \multirow{2}{*}{ 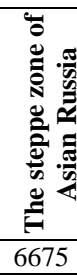 } \\
\hline \multirow{6}{*}{ Rural population (thousand people) } & 1995 & & & & & & & & & \\
\hline & 2000 & 1477 & 936 & 458 & 670 & 536 & 1247 & 684 & 671 & 6679 \\
\hline & 2005 & 1635 & 869 & 400 & 644 & 490 & 1151 & 643 & 597 & 6428 \\
\hline & 2010 & 1604 & 819 & 361 & 626 & 530 & 1092 & 605 & 563 & 6201 \\
\hline & 2015 & 1555 & 800 & 329 & 609 & 505 & 1041 & 588 & 546 & 5974 \\
\hline & 2018 & 1531 & 779 & 316 & 601 & 499 & 1010 & 584 & 529 & 5851 \\
\hline \multirow{6}{*}{$\begin{array}{l}\text { Agricultural population (thousand } \\
\text { people) }\end{array}$} & 1995 & 322 & 192 & 104 & 148 & - & 251 & 156 & 187 & 1358 \\
\hline & 2000 & 367 & 210 & 125 & 163 & 86,8 & 291 & 188 & 176 & 1606 \\
\hline & 2005 & 309 & 212 & 82 & 138 & 78,8 & 235 & 161 & 167 & 1384 \\
\hline & 2010 & 280 & 205 & 59 & 125 & 78,8 & 216 & 121 & 149 & 1233 \\
\hline & 2015 & 223 & 192 & 49 & 125 & 74 & 205 & 102 & 137 & 1109 \\
\hline & 2018 & 131 & 135 & 31 & 91 & 44 & 130 & 79 & 109 & 749 \\
\hline \multirow{6}{*}{ The level of ruralization (\%) } & 1995 & 21.9 & 24.0 & 21.2 & 21.6 & - & 19.6 & 22.0 & 26.7 & 20.3 \\
\hline & 2000 & 24.8 & 22.5 & 27.2 & 24.4 & 16.2 & 23.3 & 27.4 & 26.2 & 24.0 \\
\hline & 2005 & 18.9 & 24.4 & 20.5 & 21.4 & 16.1 & 20.4 & 25.1 & 28.1 & 21.5 \\
\hline & 2010 & 17.5 & 25.0 & 16.3 & 20.0 & 14.9 & 19.7 & 20.0 & 26.5 & 19.9 \\
\hline & 2015 & 14.4 & 24.0 & 14.9 & 20.6 & 14.7 & 19.7 & 17.4 & 25.2 & 18.6 \\
\hline & 2018 & 8.6 & $\begin{array}{l}17.3 \\
\end{array}$ & 9.8 & 15.0 & 8.8 & 12.9 & 13.5 & 20.6 & 12.8 \\
\hline
\end{tabular}


These two largest agrarian-social megaprojects formed a landscape view, a structure of the land fund and agrarian specialization in steppes of Trans-Volga, South Ural and West Siberia for decades to come. As a result of realization of these two projects, steppe in Ural and Siberia underwent a powerful anthropogenic stress with a loss of the landscape diversity, degradation of the soil cover, reduction of biological resources.

A retrospective analysis of a scale of arable squares occupied by agricultural crops for 1913-2018 was conducted to estimate the dynamics of agricultural development within the territories [17, 18] (Fig. 1). An increase of the squares with agricultural crops had been uniformly, the respective indicator grew in average in 1.7 times from 19.1 million hectares to 11.2 million hectares from 1913 to 1950 . In total, within the examined territory about 10 million hectares of virgin lands was transformed into arable lands from 1954 to 1960 (Table 2).
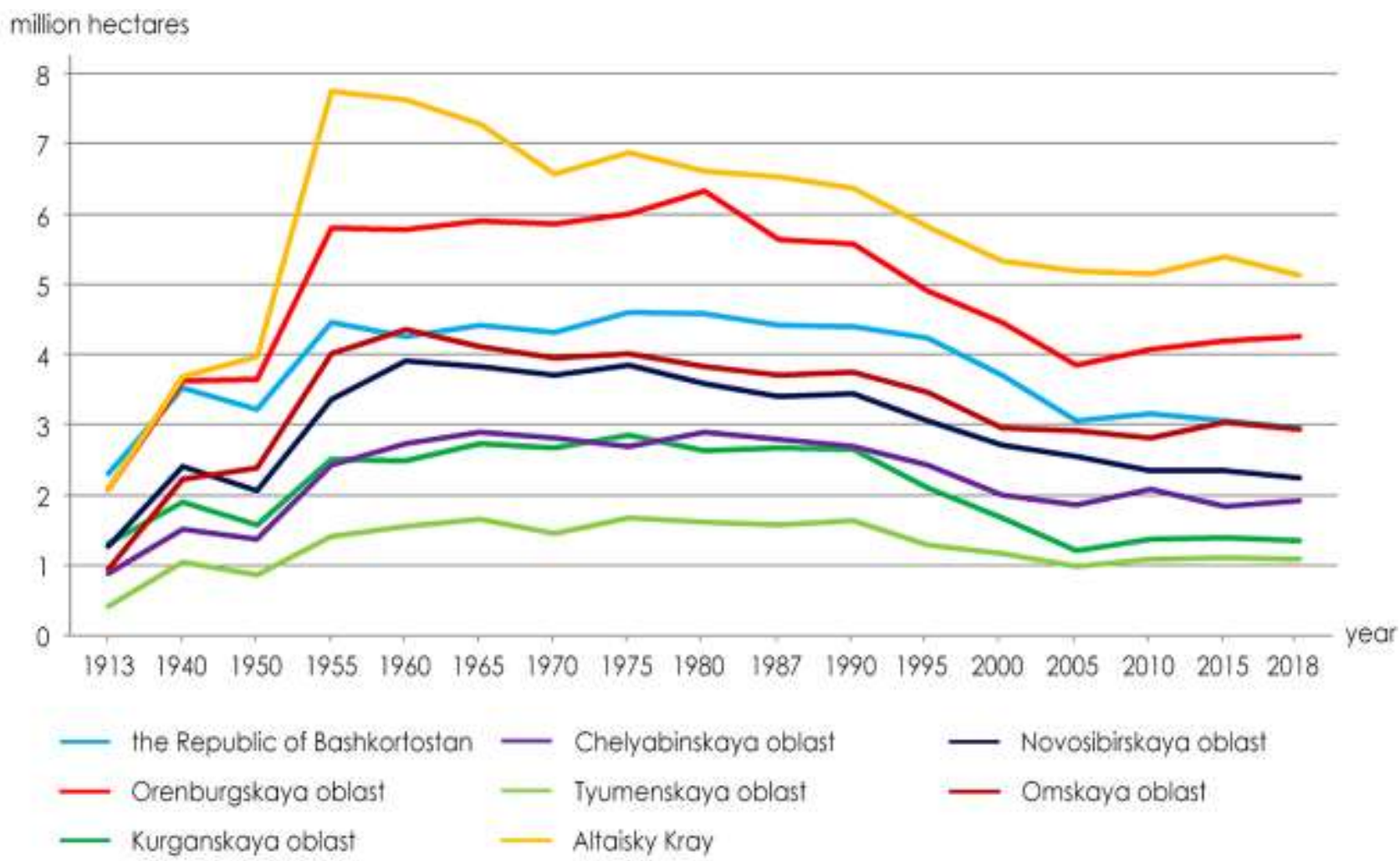

Fig. 1. Dynamics of sown areas under agricultural crops in the steppe regions of Asian Russia.

TABLE II. DYNAMICS OF SQUARES OF PLOUGHED VIRGIN AND FALLOW LANDS IN THE STEPPE REGIONS OF ASIAN RUSSIA, 1954 - 1960

\begin{tabular}{|l|c|c|c|c|c|c|c|}
\hline \multirow{2}{*}{ Region } & \multicolumn{7}{|c|}{ Square of ploughed up virgin and fallow lands } \\
& \multicolumn{1}{|c|}{ (thousand hectares) } \\
\cline { 2 - 9 } & $\mathbf{1 9 5 4}$ & $\mathbf{1 9 5 5}$ & $\mathbf{1 9 5 6}$ & $\mathbf{1 9 5 7}$ & $\mathbf{1 9 5 8}$ & $\mathbf{1 9 5 9}$ & $\mathbf{1 9 6 0}$ \\
\hline $\begin{array}{l}\text { The Republic of } \\
\text { Bashkortostan }\end{array}$ & 380 & 116 & 28 & 22 & 12 & 1 & 5 \\
\hline $\begin{array}{l}\text { Orenburgskaya } \\
\text { oblast }\end{array}$ & 1052 & 285 & 0 & 59 & 1 & 0 & 0 \\
\hline $\begin{array}{l}\text { Kurganskaya } \\
\text { oblast }\end{array}$ & 248 & 157 & 0 & 102 & 24 & 2 & 3 \\
\hline $\begin{array}{l}\text { Chelyabinskaya } \\
\text { oblast }\end{array}$ & 505 & 219 & 37 & 60 & 39 & 17 & 11 \\
\hline $\begin{array}{l}\text { Tyumenskaya } \\
\text { oblast }\end{array}$ & 228 & 132 & 25 & 166 & 35 & 27 & 107 \\
\hline Altaisky Kray & 2311 & 392 & 39 & 45 & 64 & 13 & 9 \\
\hline $\begin{array}{l}\text { Novosibirskaya } \\
\text { oblast }\end{array}$ & 668 & 288 & 80 & 362 & 100 & 26 & 25 \\
\hline Omskaya oblast & 943 & 170 & 20 & 63 & 61 & 61 & 81 \\
\hline Total & 6335 & 1759 & 229 & 879 & 336 & 147 & 241 \\
\hline
\end{tabular}

A square of sown areas changed to a very little degree until the USSR collapsed. A scale reduction of sown areas happened in the end of XX century. In 1990-s the square of sown areas in the steppe regions of Asian Russia reduced almost at $1 / 3$ from 30 to 22 million hectares. It touched, in the most degree, Orenburgskaya oblast (the square of sown areas reduced at 1507 thousand hectares), Kurganskaya oblast (at 1266 thousand hectares), the Republic of Bashkortostan (at 1252 thousand hectares) and Altaisky Kray (at 1230 thousand hectares). One of the reasons of such sown areas reduction was a change of the economical structure. During this period as unproductive lands were stopped to be used, so highproductive areas being in a relative removal from large centers of agro-production were not developed due to economical inexpediency.

In spite of a sown areas reduction happening during a half of the century, agricultural lands still prevail in the structure of 
the land fund within the examined region (Fig. 2). It should be noted that Orenburgskaya oblast is the only region where a part of agricultural lands exceeds $70 \%$, and Tyumenskaya oblast is the only region where the square of the forest fund is more than the agricultural fund.

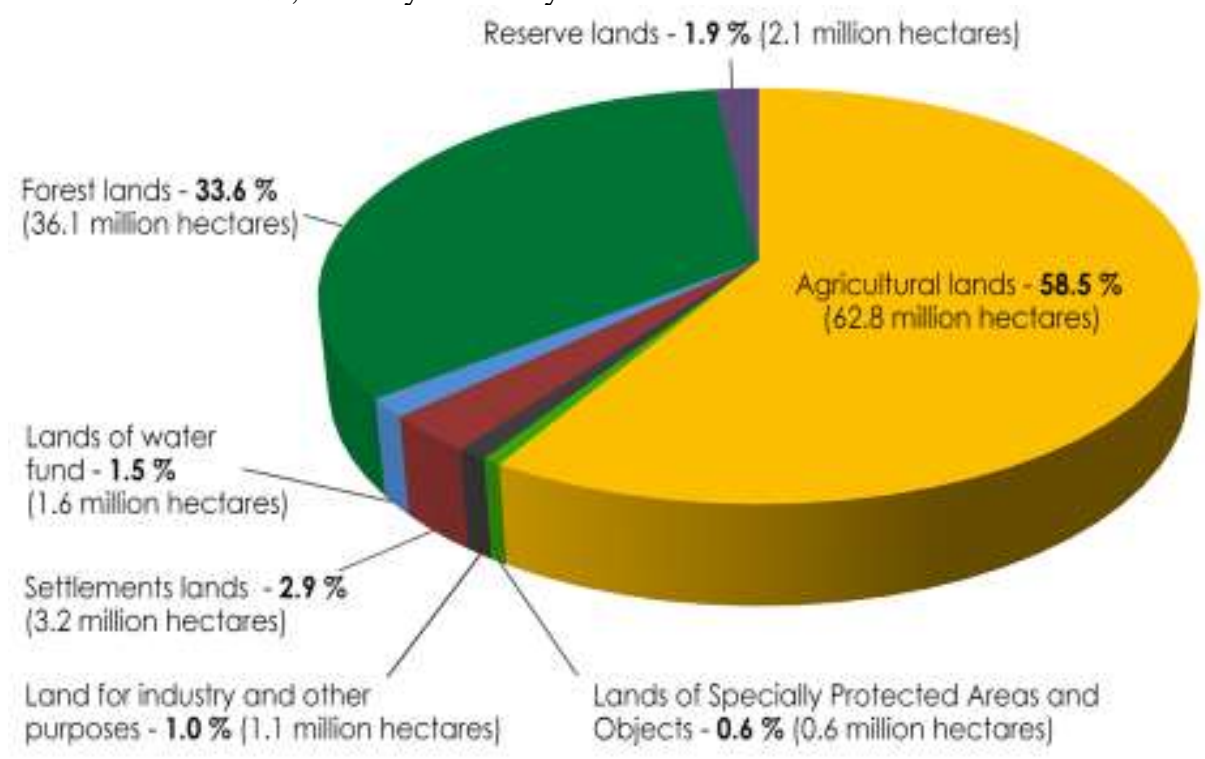

Fig. 2. A structure of the land fund in the steppe regions of Asian Russia.

In 2018 small squares of agricultural lands (according to absolute values) are noticed in Altaisky Kray (11.5 million hectares), Novosibirskaya obaslt (11.1 million hectares) (Fig. 3a). According to a relative index of parts of agricultural lands from the total square of the subject, a maximal value, as it was mentioned above, was noticed in Orenburgskaya oblast as well as in Altaisky Kray and Novosibirskaya oblast (Fig. 3b).

The total square of agricultural lands in the steppe regions of Asian Russia is 57.2 million hectares that forms $1 / 3$ all agricultural lands in Russia (Fig. 4a). The maximal part of these areas goes to arable lands, the total square of which reaches to 31.2 million hectares or $26 \%$ of all arable lands in Russia. The largest squares of arable lands and pastures are noticed in Altaisky Kray (6.7 million hectares and 2.8 million hectares, respectively) and in Orenburgskaya oblast (6.1 million hectares and 4.0 million hectares, respectively) (Fig. 4b).

\section{DISCUSSION}

A number of rural populations have been reducing for two last decades. A number of populations living in rural areas within the steppe regions of Asian Russia were 5851 thousand people (87\% from 1995) by the end of 2018. The most reduction of population happened in Altaisky Kray (at $21 \%$ ). Reduction of rural population was noticed around all examined territories except the Republic of Bashkortostan. However according to population of the country in the whole, in the studied regions a part of rural population exceeds $40 \%$ only in the Kalmuck Republic in spite of a population reduction at 269.3 thousand people. Reduction of agricultural population followed after reduction of rural population.
Within the studied mesoregion in the whole, AP reduction was 609 thousand people, in average at 87 thousand people in each region. A reduction happened everywhere, but, in the large degree, it touched Kurganskaya oblast (in 3.4 times, from 104 to 31 thousand people). According to absolute values, the maximal reduction AP is noticed in the Republic of Bashkortostan (at 190 thousand people). On the base of a ratio AP and RP the level of ruralization (LR) during 1995-2018 was calculated for the studied regions. Thus, in the steppe zone of Asian Russia for 2018 there were no regions belonging to a category "agrarian", the most parts of the regions ( 5 of 8 regions) went to a category "diversified". The largest indicator of LR is noticed in Omskaya oblast (20.6\%), the least $-8.6 \%$ in the Republic of Bashkortostan.

Natural conditions and remoteness from the regional centers in a considerable degree formed existing fragmentation of the space of agro-production in the studied territory. One of the most significant factors of differences between agroproduction is depopulation of rural areas along with its economic and social degradation [19].

The rural area, in a considerable degree, was transformed by growing cities "thank to" which by the second part of XX century a village lost almost $30 \%$ of population under a conservation of a positive natural increase. Low indicators of ruralization level within the studied regions do not rule out a presence of existing potentials to intensify agro-production. In conditions of continuing sanctions and desire of Russia to organize self-provision by food stuff, tasks of agricultural growth come in the forefront. 

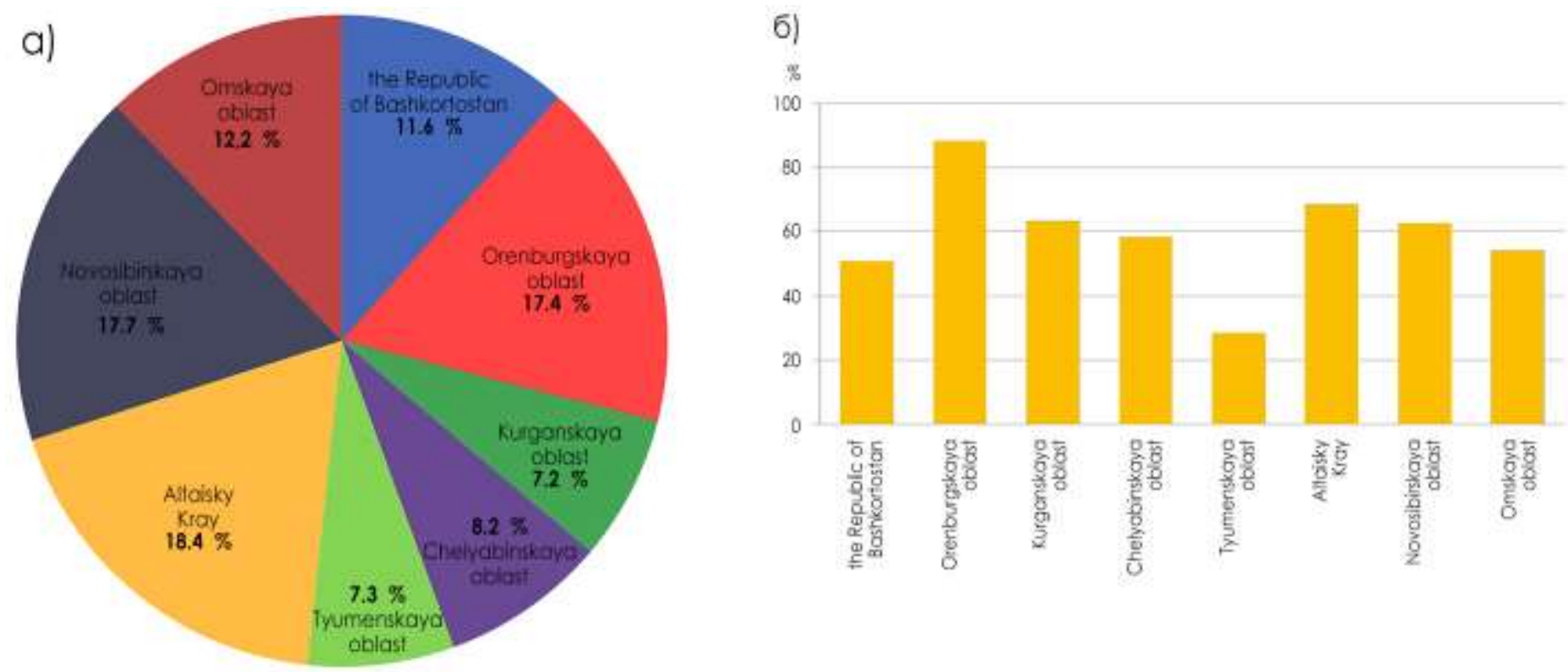

Fig. 3. Agricultural lands in the mesoregion within the steppe regions of Asian Russia: a) a structure according to the subjects; b) a part of the subjects' land fund in the structure.

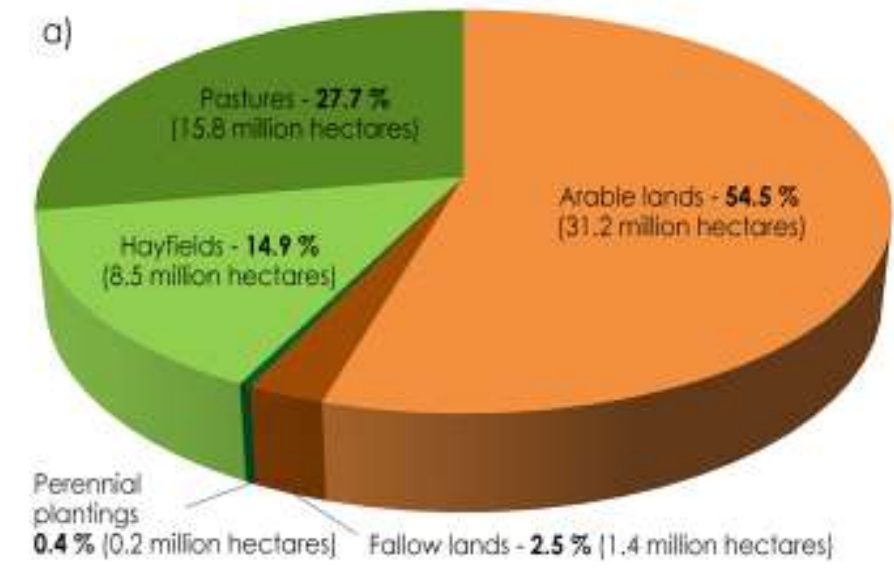

6)

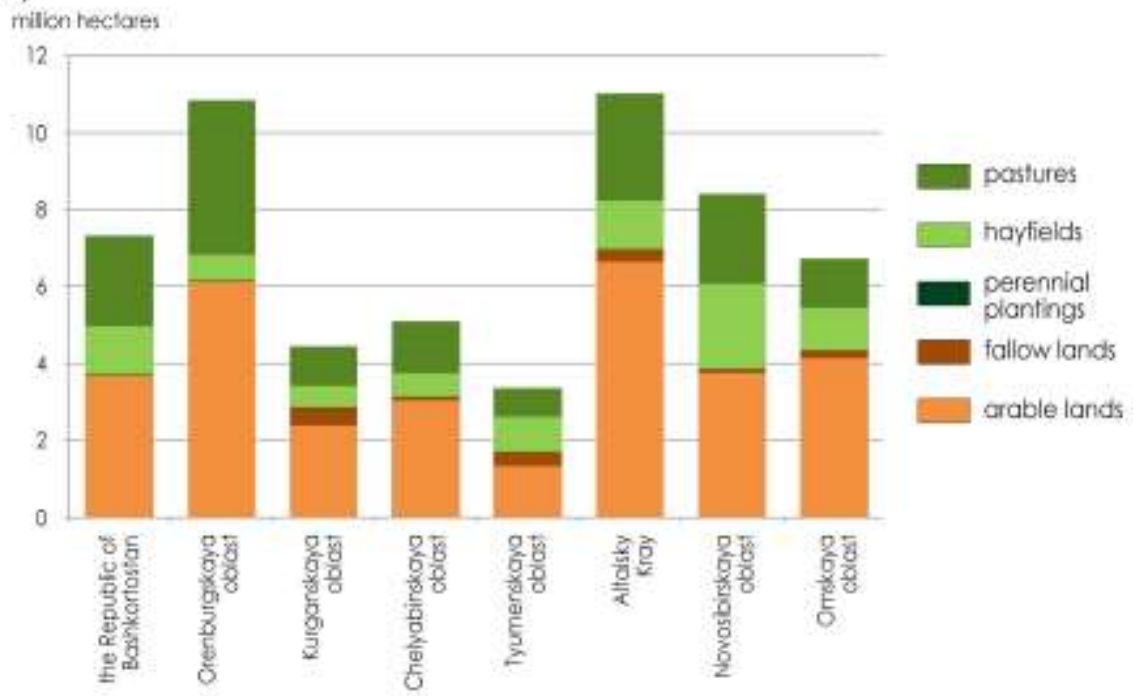

Fig. 4. The structure of agricultural lands of: a) a mesoregion within the steppe regions of Asian Russia; b) in the context of the subjects. 


\section{CONCLUSION}

A schematic map was built to visualize spatial distribution and interconnections between indicators of arable lands squares, the level of ruralization and structure of agricultural lands (Fig. 5).

The level of ruralization conditioned by social-economical factors in less degree correlates with a part of agricultural lands and a square of arable lands in Omskaya oblast. Under the maximal level of ruralization $(20.6 \%)$ an excess of average values of agricultural areas and arable lands is minimal within the studied mesoregion. Correspondence of the studied indicators is noticed in Tyumenskaya oblast: the least part of agricultural lands (4.6 million hectares), the least square of arable lands ( 1.4 million hectares) and the low level of ruralization $(8.8 \%)$.

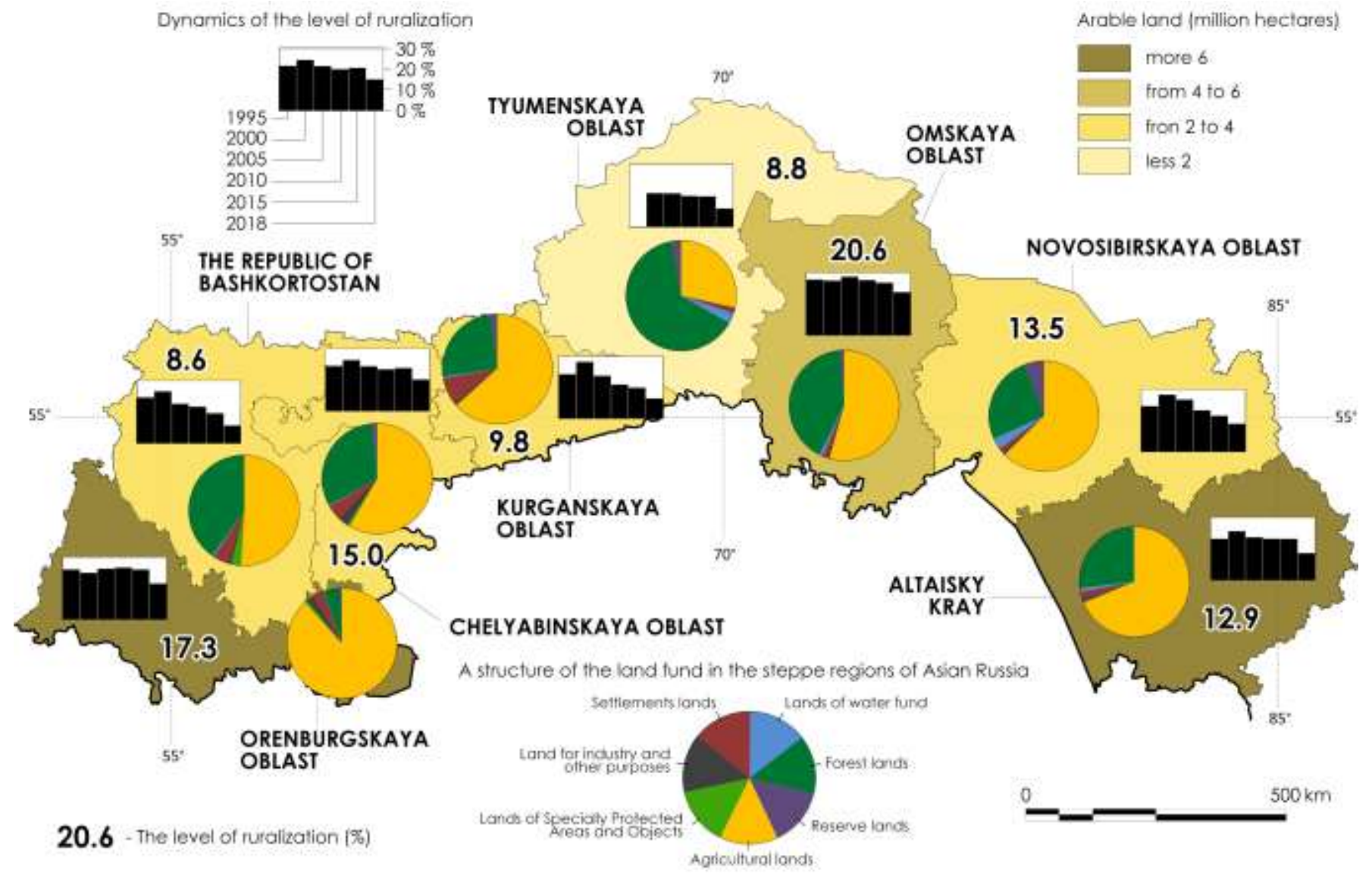

Fig. 5. A schematic map of the land fund structure, squares of arable lands and the dynamics of the level of ruralization in the steppe regions of Asian Russia

Stable trends to reduce the level of ruralization are the most evident in the Republic of Bashkortostan, Kurganskaya and Novosibirskaya oblasts for the last quarter of the century.

Problems to organize a rational use of natural-resource and social-economical potential in the rural area within the regions in the steppe zone of Asian Russia should be solved along with tasks of stable diversification of the rural economy.

Choosing ways of diversification, the local government should be guided by the following principals: to realize a principal competitive advantage; to keep a positive impact of the ecological factor providing development of basic sphere of economy in rural territories (agriculture, fishery, forestry, the touristic-recreational sphere); to harmonize interests of each subject of economical activity in rural territories.

\section{Acknowledgment}

The study was conducted under the financial support by the RSF grant 20-17-00069 "Geographical basis of spatial development in agricultural virgin lands regions within Ural and Siberia".

\section{References}

[1] A.S. Nekrich, D.I. Lyuri, "Factors of the arable land dynamics in the crisis period in the provincial scale (on the example of Kurskaya oblast)", Izv. of the Russ. Acad. of Sci. Geogr. Ser., no. 1, pp. 123-130, 2016.

[2] A.S. Nekrich, D.I. Lyuri, "Changes of the dynamics of agrarian lands in Russia during 1990-2014", Izv. of the Russ. Acad. of Sci. Geogr. Ser., no. 3, pp. 64-77, 2019.

[3] A.A. Chibilev, V.P. Petrishchev, S.V. Levykin, G.V. Kazachkov, A.K. Ashikkaliev, "The soil-ecological index as an integral indicator for the optimization of the land-use structure", Geogr. and Natural Res., vol. 37 , no. 4 , pp. 348-354, 2016. 
[4] Yu.A. Gulyanov, A.A. Chibilev, S.V. Levykin, M.M. Silanteva, G.V. Kazachkov, L.V. Sokolova, "Ecological-based adaptation of agriculture to the soil and climatic conditions in Russian steppe", Ukrainian J. of Ecol., vol. 9, no. 3, pp. 393-398, 2019.

[5] "Development of virgin lands and the modern agrarian reform in Kazakhstan", Vest. of the Moscow Univer. Ser. 5 Geogr., no. 3, pp. 48-53, 2004.

[6] V.N. Tomilin, "The Campaign of virgin and fallow lands reclamation in 1954-1959", Voprosy istorii, no. 9, pp. 81-93, 2009.

[7] S.V. Levykin, E.A. Semenov, A.A. Chibilyov (jr.), V.P. Petrishchev, Problems of land use and spatial development of the steppe regions. Moscow: Ruscience, 2018.

[8] A.I. Alexeev, N.S. Mironenko, Geography, society, environment, Vol. V. Geography of social-economical development. Moscow: Gorodets, 2004.

[9] I.M. Kuzina, "Interconnection of social-economical and ecological processes in rural areas", Vest. of the Moscow univer. Ser. 5 Geogr., no. 1, p. 10, 1996.

[10] I.M. Kuzina, "Modern transformations in geography of rural population in the world", Vest. of the Moscow univer. Ser. 5 Geogr., no. 1, pp. 17-23, 2004 ,
[11] G.M. Robinson, Conflict and change in the countryside: Rural society, economy and planning in the developed world. Chichester, 1995.

[12] S.A. Kovalyov, Rural settlement (a geographical research). Moscow: Moscow univer., 1963.

[13] A.I. Alexeev, A vilage of many faces. Moscow: Mysl, 1990.

[14] "Federal state statistics service". Russian statistical yearbook. Moscow: Goskomstat, 1995.

[15] Federal state statistics service. Regions of Russia. Social-economical indicators. Moscow: Rosstat, 2018.

[16] A.A. Chibilyov, A.A. Chibilyov (jr.), O.S. Rudneva, A.A. Sokolov, Yu.A. Padalko, D.S. Meleshkin, D.V. Grigorevsky, Problems of stable devlopment of social-economical geosystems in the steppe zone of the Russian Federation. Orenburg: IS UB RAS, 2018.

[17] National economy of the RSFSR in 1958. Statistical yearbook. Moscow: Gosstatizdat, 1959.

[18] Federal Service for State Registration, Cadastral Records and Cartography. The state (national) report on lands state and use in the Russian Federation. Moscow: Rosreestr, 2018

[19] Sustainable Agriculture and Rural Development World Experience and Problems of Russia. Moskow: KMK Press, 2005. 